\title{
Constraints on Poverty Reduction Cooperation Under the Lancang- Mekong Cooperation Mechanism
}

\author{
Li Jiacheng and \\ Li Zengtaozi
}

\begin{abstract}
Poverty is the biggest problem standing in the way of economic development and political stability in the Mekong River sub-region. Multilateral poverty reduction cooperation in this sub-region has long been focused on stimulating economic growth through increased investment and foreign aid in such areas as environmental protection, health care, education, and vocational training. As a relatively new cooperative platform, the Lancang-Mekong Cooperation (LMC) mechanism has
\end{abstract}

Li Jiacheng is Associate Professor of the Department of International Politics, School of International Studies, Liaoning University. His mailing address is: Post Box 35, Room 215, Zexing Building, Liaoning University, 58 Daoyi South Street, Shenyang North New District, Liaoning Province 110136, China. He can also be reached at lijiacheng369@126. com. Li Zengtaozi is an MA student at the School of International Studies, Liaoning University and can be reached at 493714937@qq.com.

(C) 2019 World Century Publishing Corporation and Shanghai Institutes for International Studies China Quarterly of International Strategic Studies, Vol. 5, No. 3, 437-454

DOI: $10.1142 / S 2377740019500222$

This is an Open Access article, copyright owned by the SIIS and WCPC. The article is distributed under the terms of the Creative Commons Attribution-NonCommercial 4.0 (CC BY-NC) License which permits use, distribution and reproduction in any medium, provided that the original work is properly cited and is used for non-commercial purposes. 
played an increasingly prominent role in sub-regional economic development and integration; and a joint task force has been set up to draw up multilateral initiatives and plans better tailored to local conditions and needs. Nonetheless, the LMC must increase its relevance and effectiveness in poverty reduction by complementing and coordinating with other existing sub-regional programs amid intensifying power competition in the broad Indo-Pacific region, while taking into account different national development philosophies as well as rising environmental and resource concerns.

Keywords: Lancang-Mekong Cooperation (LMC); poverty reduction; subregional development; institutional compatibility.

Since the formal launch of the Lancang-Mekong Cooperation (LMC) mechanism in March 2016, closer coordination among its member states China, Myanmar, Laos, Thailand, Cambodia and Vietnam - has yielded much concrete progress, especially in agriculture, education, medical care, and poverty reduction. Aligning specific programs with the United Nations' 2030 Agenda for Sustainable Development (UN 2030 Agenda) and other green development initiatives, LMC member states have incorporated a green poverty-reduction initiative into the overall socioeconomic development blueprint in the Mekong River sub-region, making it clear that economic growth and social progress do not need to come at the expense of the environment.

As an essential part of their joint efforts, the LMC members have also formulated the Five-year Plan for Sustainable Poverty Reduction, which is aimed at promoting experience and knowledge sharing on poverty reduction. ${ }^{1}$ In June 2016, LMC member states set up a special working group on poverty reduction responsible for tailoring various cooperation plans to the specific needs of individual nations. Integrating LMC efforts into the overall China-ASEAN (Association of Southeast Asian Nations) endeavor on poverty reduction, the member states are not only contributing to socioeconomic development of the region, but also making progress toward

1 "Speech by H.E. Li Keqiang at the Second Lancang-Mekong Cooperation Leaders' Meeting," Lancang-Mekong Cooperation, January 12, 2018, http://www.lmcchina.org/eng/ zyxw_5/t1525239.htm. 
the ASEAN Community Vision 2025. ${ }^{2}$ Moreover, the LMC has proven to be an effective mechanism for China and its ASEAN partners to strengthen poverty reduction cooperation along multilateralist lines under the framework of the UN 2030 Agenda.

In order to avoid duplication and improve the efficiency of multiple poverty-alleviating mechanisms, communication and coordination among LMC member states must be enhanced, so that the overlapping - sometimes competing - visions of local socioeconomic development can be better aligned under an overarching objective, with individual initiatives complementing and reinforcing each other. Effective measures need to be taken to redress the political dynamics that cause fragmented poverty-relief undertakings in some member states. Rising environmental and resource concerns among the local public should also be carefully addressed, for they could pose lingering obstacles to the long-term progress in poverty reduction.

\section{Institutional Overlaps and Competition}

Sub-regional cooperation in the Lancang-Mekong River Basin began in the 1990s. As the local security and strategic environment becomes increasingly complex, the existing and newly proposed cooperative mechanisms on poverty reduction, economic development, and social progress are arrayed in a pattern of "institutional overlaps," where competitive advantages of individual initiatives and programs have been weakened as a result of duplication and competition.

In the past decade, a wide variety of multilateral cooperative mechanisms for the Lancang-Mekong River Basin have been launched, contributing, in their own ways, to sub-regional poverty reduction. ${ }^{3}$

\footnotetext{
${ }^{2}$ Sun Guangyong and Zhao Yipu, “Jointly Promote Regional Development and Prosperity through China-ASEAN Poverty Reduction Cooperation [中国一东盟合作共促地区发展与繁荣], People's Daily, September 28, 2018, http://world.people.com.cn/n1/2018/0928/c1002-30317556.html.

${ }^{3}$ For detailed discussion about various multilateral cooperation mechanisms in the Lancang-Mekong Basin, see Luo Shengrong, "International Poverty Reduction Cooperation in Lancang-Mekong Subregion: State, Problems, and Reflections [澜沣次区域国际减贫合作的现状、问题与思考], Journal of Shenzhen University, No. 3 (2017), pp. 107-108; and Luo Yifu, "From the GMS to the Lancang-Mekong Cooperation: Competing International Institutions on the Indochina Peninsula [从大涺公河机制到澜涺合作: 中南半岛上的国际制度竞争]," Foreign Affairs Review, No. 6 (2018), p. 122.
} 
For example, ASEAN-Mekong Basin Development Cooperation (AMBDC), the most inclusive cooperative mechanism, covers such areas as agriculture, industry, infrastructure, mineral development, investment and trade, with the aim of achieving greater regional economic integration in an inclusive and equitable way. ${ }^{4}$ Intra-regional mechanisms like the Cambodia-LaosMyanmar-Vietnam cooperation (CLMV) also emphasize the comprehensive integration of markets and economies among CLMV countries and intend to make the Mekong River Basin an inclusive and vibrant sub-region.

Two development initiatives, the Greater Mekong Sub-region Economic Cooperation Program (GMS) and the LMC, are telling examples of insufficient synergy between overlapping and competing visions of subregional development blueprints. The two initiatives overlap in terms of participants, agendas, and operational models. Memberships of the two initiatives are the same six countries as mentioned previously. Both initiatives identify effective poverty reduction as the basis for sustained economic development and social progress. While the GMS focuses on building a number of economic corridors across the sub-region to hold up an envisioned economic community, the LMC regards poverty reduction cooperation as essential to narrowing the development gap among Mekong countries and a major contribution to the fulfillment of the UN 2030 Agenda. Both initiatives place a high premium on infrastructure development, productivity growth, and cross-border trade facilitation to improve the overall socioeconomic foundation of the sub-region. The two initiatives also operate through similar institutional structures, i.e., a three-tiered working arrangement of leaders' summits, ministerial conferences, and working group consultation on priority sectors. In terms of funding, the GMS largely depends on the Asian Development Bank (ADB), whereas the China-initiated LMC looks to the Asian Infrastructure Investment Bank (AIIB) to finance its projects and programs.

Launched more than two decades after the GMS's inauguration, the LMC needs to

The GMS and LMC largely overlap in participants, agendas, and operational models.

${ }^{4}$ Zhou Shixin, “Lancang-Mekong Cooperation: Impetus, Characteristics, and Prospects [澜沧江一湄公河合作机制: 动力、特点和前景分析]," Crossroads: Southeast Asian Studies, No. 1 (2018), p. 73. 
further integrate into sub-regional development cooperation programs by better coordinating with other bilateral and multilateral initiatives and closely aligning with individual countries' development plans. As a late comer caught up in an increasingly complex sub-regional development landscape, the LMC also needs to introduce more open and inclusive programs that seek to complement and back up rather than undermine or replace the existing sub-regional development plans.

\section{Outsiders' Outsize Influence}

A mosaic of overlapping cooperative mechanisms led by countries outside the sub-region far exceeds the actual needs in the Lancang-Mekong River Basin. The poverty reduction projects in the Basin are all led by regional powers with strong economies; and the mutually exclusive development programs among these powers reflect their increasing competition over influence in the sub-region, which exacerbates the incompatibility of multilateral mechanisms. In fact, the geo-strategic value of the Indochina Peninsula has made intensified great power competition in the LancangMekong River Basin even more inevitable.

Given China's obvious geographical advantage in the sub-region, extraterritorial countries led by the United States worry that China would continue strengthening its regional influence by creating an institutional framework enshrining its regional leadership position. To balance against it, the United States, Japan, South Korea, and India have stepped in and coopted sub-regional countries to add to their geopolitical and geo-economic weight.

Australia, the European Union, and Russia have also declared interests in the region. Australia is concerned about the process of sustainable development in the Mekong River Basin, focusing on supporting infrastructure development and strengthening water resource management. Some European countries are committed to promoting democracy, human rights, environmental protection, and poverty alleviation in Mekong River countries, aiming to expand the political influence of the EU. Russia has carried out energy cooperation and trade investment with Southeast Asian countries in the Mekong River Basin, proposed to establish a unified sub-regional development plan, and sought to participate in all the cooperative 
mechanisms in the Mekong River Basin. ${ }^{5}$ Without an overarching framework that is capable of integrating all the regional poverty-alleviating programs, the intensifying contest for regional leadership and divergent visions for sub-regional development may hinder rather than help LMC countries' individual and collective efforts to promote sustained growth and stability.

The United States continues to focus on Mekong affairs and is one of the leading proponents of cooperative mechanisms in the region. Over the decades, Washington has set up a number of local development initiatives, such as the Lower Mekong River Basin Survey and Coordination Commission, the Mekong Transition Commission, and the Mekong River Commission. During the Vietnam War, the United States attached great importance to the strategic position of the Mekong River region and gave strong support to pro-U.S. governments for the development of the Mekong economy. ${ }^{6}$ After the end of the Cold War, Washington adjusted its policy toward countries of the Mekong River Basin, focusing on strengthening its strategic position vis-a-vis emerging powers like China and helping regional economies integrate into global value chains.

The Lower Mekong Initiative (LMI) was launched by former President Obama in his first year in office. The Lower Mekong Action Plan under the LMI framework is a detailed roadmap that strengthens cooperation between the United States and Lower Mekong countries in such areas as energy, agriculture, environment, water management, and food security. At the 11th ministerial meeting of the Lower Mekong Initiative in August 2018, member states highlighted the contribution of the mechanism to economic integration and sustainable development in the Mekong River Basin, and approved a joint plan to update and streamline the mechanism's work flow.

\section{The U.S. worries} about being excluded from the China-led Mekong River sub-region.

${ }^{5}$ Bi Shihong, “Institutional Congestion or Concert of Great Powers? Outside Powers' Involvement in Mekong River Basin Development Cooperation [机制拥堵还是大国协调一 区域外大国与滽公河地区开发合作]," Journal of University of International Relations, No. 2 (2013), p. 65.

${ }^{6} \mathrm{Tu} \mathrm{Su}$, "The United States and the Mekong Basin Development Project [美国与涺公河开发计划探研]," Wuhan University Journal, No. 2 (2013), pp. 122-123. 
For a long time after the Cold War, the United States has been the dominant external power in the Lower Mekong sub-region, promoting its development model and political values to win over the hearts and minds of local residents. However, with the rise of China, the unipolar power structure in the sub-region is beginning to change as U.S. economic and political influence wanes in the wake of the 2008 financial crisis as well as the protracted wars in Afghanistan and Iraq; at the same time, China's regional influence has been rising since it overtook Japan as the world's second largest economy and launched a number of cooperative mechanisms to promote regional integration. ${ }^{7}$ With the rapid growth of the ChinaASEAN partnership and Beijing's friendly relations with individual nations, Washington is increasingly concerned that a Chinese-led sub-region may exclude American interests and presence. Against this backdrop, beginning in the first term of the Obama administration, the United States has stepped up its bilateral diplomacy toward Vietnam, Laos, Thailand, and Myanmar by either building defense partnerships and increasing foreign aid, or consolidating military cooperation and relaxing economic sanctions.

The recent U.S. diplomatic activism in the sub-region serves multiple purposes in addition to countering China's growing presence, among which promoting American-style democracy and human rights is one of the most important. Indeed, the United States has been encouraging and facilitating homegrown and foreign nongovernmental organizations in the sub-region, supporting their participation in public policy making. Washington also provides financial means for local opposition parties and civil groups to organize mass protests as a way of pressuring local governments to move in the direction favored by the United States - "peaceful evolution" as many call it. During the Cold War, Washington exerted enormous influence on domestic politics of the sub-region, trying to turn it into an anti-communist fortress. After the end of the Cold War, vehement U.S. criticism of such countries as Vietnam and Myanmar for human rights abuses continues. More recently, Washington reduced its economic assistance to Cambodia for Phnom Penh's allegedly rigged elections and imposed crippling economic sanctions on Myanmar for failing to fulfil its commitments on democratic reforms. Washington has also leveraged its alliance with

${ }^{7}$ Liu Zhi, ed., Report on the Development of the Lancang-Mekong Cooperation (Beijing: Social Sciences Academic Press, 2017), p. 37. 
Thailand to intervene in the latter's political affairs, expressing dissatisfaction about the repeated military coups in the country.

In recent years, sub-regional cooperation on poverty reduction has become more difficult as Washington and Beijing are locked in a long-term geopolitical and geo-economic competition where room for pragmatic cooperation on non-traditional issues is shrinking. Sub-regional countries also find it difficult to maintain a neutral and detached position between the two great powers. Any innocent-looking move or preferential policy toward either side may be perceived as a real or potential challenge to the other. When the spill-over effect of geopolitical competition is felt in economic and development cooperation, and pragmatism gives way to ideological and institutional competition, incompatibility and inconsistency in poverty reduction initiatives only become more glaring.

Japan has long been active in Southeast Asia and played an important role in poverty alleviation in the Mekong River sub-region. Tokyo's involvement in sub-regional poverty reduction mainly takes the form of financial assistance and infrastructure building. The Mekong River subregion is included as a key arena of Japan's Indo-Pacific strategy because an open and free Indo-Pacific presupposes a stable and neutral sub-region that stays out of any sphere of influence. In 1993, Japan put forward a sweeping Mekong development cooperation plan and set up a Greater Mekong Development Committee to guide related cooperation. On the first Japan-Mekong foreign ministers' meeting in 2008, Japan pledged to press ahead with the construction of economic corridors and gradually increase official development assistance (ODA) to facilitate the integration of trade and investment in the Mekong River sub-region. ${ }^{8}$ Since 2009, Japan has held regular summits with sub-regional leaders. Through economic assistance, Japan has deepened its partnership with Mekong River countries mainly through cooperation in infrastructure building, water resource management and, more in recent years, poverty reduction.

Japan is a leading actor in sub-regional cooperation in poverty reduction.

${ }^{8}$ Wang Di and Tao Jun, “Multiple Outcome Documents Adopted at GMS Leaders' Meeting [大涺公河次区域经济合作领导人会议通过多项成果文件]," People's Daily, April 2, 2018, http://world.people.com.cn/n1/2018/0402/c1002-29901162.html. 
Up to the present, Japan has formulated a series of documents, such as the Tokyo Strategy 2012, the New Tokyo Strategy 2015, and the Tokyo Strategy 2018, proposing to focus on improving the road, railway, and power facilities in the Mekong River sub-region. In addition, Japan is seeking to carry out in-depth cooperation with sub-regional countries on such issues as response to climate change, water pollution control, and high-quality personnel training. In the Tokyo Strategy 2018, Japan stresses that it will continue providing government development assistance to help Mekong River countries reduce poverty in order to build a "Green Mekong River Basin" with no gap and no poverty. ${ }^{9}$ Japan is particularly concerned about economic cooperation and expanding investment in the Mekong River subregion. Under the GMS framework, Japan has endorsed the Hanoi Plan of Action 2018-2022 and the Regional Investment Framework 2022, pledging economic assistance and technical investment of nearly $\$ 66$ billion; ${ }^{10}$ at the same time, Japan has been playing an active and important role in the ASEAN-Mekong River Basin development cooperation mechanism.

Japan's poverty reduction cooperation in the Mekong River sub-region provides a good example of pragmatism and empathy for the actual needs of recipient countries. As most of the Mekong River countries rely on agriculture, Japan has pledged to provide loans to Laos, Cambodia, and other countries to build irrigation facilities to improve agricultural productivity. As a result, local governments and residents generally have a favorable view of Japan's aid and development programs and welcome Tokyo's greater involvement in the sub-region. In contrast with Japan, LMC poverty reduction cooperation started rather late and its programs are much less recognized. In the short run, LMC programs should focus on more pragmatic goals like enhancing its presence and recognition by delivering more concrete benefits to local populations. For a late comer's advantage is that it can learn from others' mistakes and draw up development plans that are better tailored to the local population's needs.

\footnotetext{
${ }^{9}$ Tamiyuki Kihara and Ryuta Sometaya, "Mekong-Japan Partnership Strategy Agreed at Tokyo Summit," Asahi Shimbun, October 9, 2018, http://www.asahi.com/ajw/articles/ AJ201810090036.html.

10 “GMS Economic Cooperation Program: Regional Investment Framework 2022," Asia Development Bank, March 2018, https://www.adb.org/documents/gms-economic-cooperation-program-regional-investment-framework-2022.
} 
Taking the opportunity of the Korea-Mekong Development Forum, South Korea initiated the Korea-Mekong Foreign ministers' Meeting in 2011 and established a dialogue mechanism with the Lower Mekong River countries. In addition to reviewing the outcomes of the Five Mekong River Countries-Korea Action Plan (2014-2017) at the 7th Five Mekong River Countries-Korea Foreign Ministers' Meeting, South Korea drafted with the countries a long-term cooperation plan for the period from 2017 to 2020. Specific projects include the construction of transnational economic corridors, infrastructure development, e-commerce platform building, agricultural productivity improvement, and water resource management.

South Korea's Mekong development strategy has helped enhance friendly relations with Mekong River countries and benefited both South Korea and Mekong River countries. Over the past two years, President Moon Jae-in's government has been pursuing a "New South Policy" in Southeast Asia, strengthening economic cooperation and increasing South Korea's involvement in the ASEAN's economic integration. In particular, Seoul has upgraded its relationship with Vietnam, one of the most dynamic emerging economies in Southeast Asia that attract growing investment from South Korea. High-level visits to each other become more frequent. In 2018, the South Korea-Mekong Peace Forum was held in Vietnam, where the South Korean government endorsed Vietnam's role as a bridge in the political and security situation on the Korean Peninsula, and Hanoi reciprocated by saying that Vietnam was ready to share its positive experience in national reunification, post-conflict development, and regional economic integration. $^{11}$

As one of the most concerned neighbors to the sub-region, India initiated the MekongGanges Cooperation Initiative (MGC) in 2000 with Myanmar, Laos, Thailand, Cambodia, and Vietnam to promote cooperation in tourism, culture, education, and transportation. Since 2012, India has promoted the MekongGanges Ministerial Conference and increased

India is also stepping up economic cooperation with Mekong River countries.

11 “Korea-Mekong Peace Forum Puts Vietnam-ROK Cooperation in Spotlight," People, May 11, 2018, https://en.nhandan.org.vn/politics/item/6142702-korea-mekong-peace-forumputs-vietnam-rok-cooperation-in-spotlight.html. 
project cooperation in such new areas as the development of small- and medium-sized enterprises, crop cultivation, and epidemic prevention. Through financial support for the Mekong River countries, India is moving ahead with the India-Myanmar-Thailand road project and discussing ways to effectively enhance India-ASEAN connectivity. India is also working with sub-regional countries to address climate change and environmental issues and to propose viable options for reasonable use of water resources. At the 9th Mekong-Ganges ministerial meeting, the Mekong River countries pledged to work closely with India to remove trade barriers and forge tighter regional supply chains.

Acting on its "Look East Policy," India has gradually promoted the construction of economic corridors in the Mekong River Basin, trying to build an economic network connecting the Mekong River Basin and the Ganges River Basin. New Delhi has also strengthened bilateral diplomacy within various multilateral Mekong-related cooperative mechanisms. For India, the Mekong-Ganges initiative can take full advantage of its geography to build a cultural identity and help forge close ties with the Indochina Peninsula, since the Peninsula serves as a springboard to Southeast Asia, enabling India to effectively link the Indian Ocean with the Pacific Ocean, and helping India to strengthen its influence in East Asia. ${ }^{12}$

\section{Poverty Reduction Mired in Domestic Uncertainty}

Like the ASEAN itself, Mekong River countries are characterized by political diversity. Laos and Vietnam are socialist countries, whose domestic reforms have generated much progress in poverty reduction. Myanmar and Thailand have undergone periods of instability as national governments changed hands frequently in recent years. Cambodia's ruling class remains relatively stable, but is accused by the West of rampant corruption. Political stability in these countries is of vital importance to economic development in the sub-region, for an unstable domestic environment hinders the

12“Joint Ministerial Statement for the 9th Mekong-Ganga Cooperation Ministerial Meeting in Singapore," Ministry of External Affairs of the Republic of India, August 4, 2018, https://www.mea.gov.in/Speeches-Statements.htm?dtl/30237/Joint_Ministerial_Statement_ for_the_9th_Mekong_Ganga_Cooperation_Ministerial_Meeting_in_Singapore. 
progress of international cooperation and the great role of the LMC in poverty reduction.

\section{Myanmar: Troubled by Democratic Transition}

In Myanmar, severe poverty has led to a lack of foundation for statebuilding; and the low-level state-building, in turn, has negative effect on economic development and poverty reduction. Sanctions imposed by Western countries and domestic instability have long limited Myanmar's participation in international affairs as well as its investment in domestic economic development. A large number of people in Myanmar have fallen into poverty or returned to poverty as a result of lack of momentum for economic development resulting from the ongoing political unrest.

Despite the incremental progress achieved over the past decade, hostility and prejudice against Myanmar has grown under the pressure from Western countries on human rights issues. For a long time, Western countries have tried to introduce their ideology and values to Myanmar, in order to promote Myanmar's political transformation and shape its foreign policy. In the wake of the Rohingya crisis that erupted in 2018, the West reacted by imposing sanctions and isolated Myanmar with international condemnation. Subsequently, Myanmar's relations with the West - much improved after the end of the military rule since 2015 - soon deteriorated. In particular, some Western countries have pushed the International Criminal Court to interrogate Myanmar military officers involved in issues of the Rohingya people, and tried to push through a United Nations Security Council resolution after a condemning report on the Rohingya crisis. ${ }^{13}$ Due to the difficulties of political transition, as the ruling status of the National League for Democracy is challenged, Myanmar may again fall into longterm political turmoil.

The increasingly complex ethnic issues in Myanmar have also exerted an impact on poverty reduction cooperation. The estrangement and conflict among ethnic groups persists in Myanmar; and the central government's tendency toward consolidating power in its own hands has led to fierce resistance by local forces. Ethnic conflicts and external pressure have

${ }^{13}$ Li Chenyang and Meng Zijun, “Serious Setback in Myanmar's Relations with Western Countries [缅甸与西方国家关系出现严重倒退]," World Affairs, No. 22 (2018), p. 73. 
dimmed Myanmar's prospects for political reconciliation and economic development. There has been widespread resentment and antipathy to-

Due to domestic instability, some Mekong River countries cannot fully engage in LMC poverty-relief programs. ward the National Ceasefire Agreement, as local ethnic authorities accuse the central government of not living up to the principle of ethnic autonomy. Disarmament talks have come to a halt. Border conflicts remain far from abated. At present, Myanmar's participation in LMC poverty-alleviating programs is distracted and half-hearted, as peacebuilding and social stability remain top priorities for the central government.

\section{Thailand: Military-Civilian Relationship in Flux}

The relationship between the military and civilian leaderships has never been stable in Thailand. Competition among political parties has so much paralyzed the ruling class that broad-based consensus is far beyond reach. The military continues to wield overwhelming influence over national and local politics; and civilian leaders cannot implement any meaningful reform without the implicit or explicit support from the military's top brass. In 2014, Thai Prime Minister Prayut Chan-o-cha came to power in a military coup and took over the country's administration, putting the democratic process in a quandary. Sticking to the traditional approach, Thailand's military tends to overthrow the government when it is deemed to have made improper decisions, which is detrimental to Thailand's political stability and limits the effectiveness of its economic development.

In fact, Thailand has a long history of military intervention in politics, with the political system entrusting state power to the military junta. With the relaxation of Thailand's military control system and the undercurrent beneath the relatively stable political situation in recent years, the development of party politics has once again come to a crossroads. The military junta, the royalists, the urban middle class, the PHEU Thai Party-Thaksin Shinawatra faction, the Democratic Party-Abhisit Vejjajiva faction, and other forces are already locked in a new round of power games. ${ }^{14}$ Although

${ }^{14}$ Zhou Fangye, "Party Politics Return in Thailand: Prospects and Challenges [泰国政党政治回归的前景与挑战]," Contemporary World, No. 5 (2018), p. 59. 
the military leadership has repeatedly stated that it will restore a democratic and rule-of-law environment in the country, a number of laws and decrees as well as strategic development plans involving political reforms have provided favorable conditions for the military government to remain in power. Moreover, although Thailand's economic development largely depends on trade with China, the military government is wary of ChinaThailand economic exchanges and does not want to be tied up politically by China. For although the LMC emphasizes wide consultation and concerted efforts, nearly all the projects involving poverty reduction planning are coordinated by China, reflecting China's development philosophy to varying degrees. Thus, Thailand may only participate selectively in poverty reduction and development projects under the LMC.

\section{Cambodia: Mired in Corruption Allegations}

Cambodia's long colonial history has resulted in its low level of national cohesion and state authority, which has affected its poverty reduction effectiveness. Cronyism is allegedly widespread at all levels of government and corruption is said to have extended to all areas of social life. Indeed, Cambodia has been identified as the most corrupt country in Southeast Asia for four consecutive years. According to data released in 2018 by Transparency International, a nongovernmental organization that compiles the global corruption index, Cambodia ranked 161st out of nearly 180 countries in the corruption perceptions index (CPI), and the third from bottom in the Asia Pacific region. ${ }^{15}$ Reportedly, the integrity of elections in Cambodia has also been affected by corruption, which creates a fragile and volatile political environment.

${ }^{15}$ The corruption perception index (CPI) is also known as the incorruptibility index, and was proposed by Transparency International in 1995. The organization is committed to evaluating subjective perceptions of corruption situations in countries all over the world and providing the rankings of data and information, with the purpose of preventing abuses of power and protesting against bribery and secret deals. The CPI is assessed in a range of 0-100. The higher the score, the lower degree of corruption the country has. The CPIs of Cambodia were 21, 21, 21, and 20 respectively from 2015 to 2018. This shows that corruption in Cambodia persists and shows no sign of improvement. See "Corruption Perceptions Index 2018," Transparency International-The Global Anti-Corruption Coalition, https:// www.transparency.org/cpi2018. 
The lack of efficient public management in Cambodia in the process of social transformation requires, in particular, major reforms in the areas of party accountability and decentralization. Although the Cambodian People's Party, the nation's dominant ruling party, pursues a single-party political system, political resistance and opposition remain strong and conflict of interests often results in political paralysis. In recent years, extreme political forces continue to fuel popular discontent and foment mass disobedience. In this context, lasting economic development and poverty reduction can hardly be guaranteed.

Political turmoil in some Mekong River countries derives partly from foreign interference.

The political turmoil in Cambodia also stems from foreign interference. Cambodia's economy and security have long relied on foreign aid. In order to control Cambodia and protect their advocates in the country, Western countries often threaten to cut aid and impose economic sanctions, ignoring the actual needs for Cambodia's development and political stability. ${ }^{16}$ For instance, the United States has been actively involved in domestic politics in Cambodia by a variety of means, such as holding back foreign aid, exerting diplomatic pressure, supporting anti-government forces, and fueling public hatred toward the authorities, all of which cause much burden on the Cambodian government and undermine its endeavor to promote economic development and poverty reduction, including its participation in LMC projects.

\section{Environmental and Resource Curses: Nationalism on the Rise}

Based on rising nationalism, local concerns for the environment and national resources also stand in the way of effective poverty reduction cooperation. Environment and resource nationalists express strong grievances over and demand redress for the environmental damage and resource depletion as side effects of economic development. The two groups resist international efforts to alleviate poverty by exploring natural resources and

${ }^{16} \mathrm{Gu}$ Jiayun, “Cambodia Stands Resolutely Against Western Interference [柬埔寨坚拒西方干涉内政]," China Social Sciences Network, February 28, 2018, http://intl. cssn.cn/gj/gj_gjwtyj/gj_yt/201802/t20180228_3863209.shtml. 
tend to over-politicize every local or international development initiative that may deliver economic benefits at certain expense of the environment.

In retrospect, nationalism on the environment and resources played an important role in the national liberation and independence movements in the wake of the Second World War, as many countries began to make the most use of their natural resources to nurture their fledgling economies and integrate into the global economic system in ways that best served their interests. But the downsides of resource and environmental nationalism are also obvious: driving up commodity prices, greater likelihood of trade conflict, environmental degradation, and famine in poor countries. ${ }^{17} \mathrm{Al}-$ though resource nationalism is, strictly speaking, an economic issue, it is increasingly politicized. With the continuous worldwide depletion of natural resources, resource nationalism has been on the rise and begun to affect economic and trade cooperation in the Mekong River sub-region.

The Southeast Asian countries in the Mekong River Basin are rich in natural resources. Environment nationalists suspect that China and some other countries have been exploiting and exhausting natural resources while paying little attention to environmental consequences in the sub-region; and resource nationalists stress the need to regulate natural resources, set higher barriers to foreign investment, and call on governments to unilaterally adjust legal frameworks or alter established economic agreements. Considering the rapid depletion and non-renewable nature of natural resources, these countries tend to adopt more conservative resource development models, with some extreme resource nationalists calling for tighter control of domestic resources. Some local residents and nongovernmental organizations even voice strong opposition against all infrastructure projects.

As a result, cooperation on poverty reduction under the LMC framework has been seriously affected. Cambodia, for example, has

Rising

environmental and resource concerns have hindered poverty reduction cooperation. restricted the export of natural resources such as minerals and encouraged the processing of raw materials within its own country, in order to ensure

17 “Robin Harding: Nationalism Over Resources Is Worrying,” FT Chinese Network, December 10, 2012, http://www.ftchinese.com/story/001047942?full=y\&archive. 
maximum economic benefits. In Myanmar, the Sino-Myanmar gas pipeline has yet to reach its full commercial potential because of local environmental concerns and more strict legal scrutiny. The Myitsone Dam project also faces strong resistance and suspicion due to rising resource and environmental nationalism. Vietnam has laid a claim to resources in the disputed waters in the South China sea and is seeking to reaffirm its economic rights and reduce its economic dependence on foreign powers. In a word, excessive environmental protection and resource sensitivity in the Lancang-Mekong River Basin has diminished the poverty reduction effect of sub-regional cooperative mechanisms. Jealousy and suspicion toward China further undermine the joint efforts in this regard under the LMC framework.

\section{Diverging Development Philosophies}

Perhaps the biggest obstacle to poverty reduction under the LMC framework is the difference in development philosophies between China and the Lower Mekong River countries. Theravada Buddhism exerts predominant religious influence in the Mekong River Basin. Since this belief system emphasizes self-improvement and transcendence and values spiritual enrichment and fulfillment, people of the Mekong River Basin generally have a stronger sense of satisfaction in their daily lives and are not quite concerned about state affairs. The concept of social progress and development remains weak. Along the Lancang-Mekong River, the social context has created a social psychology of drawing satisfaction from the status quo. The poor populations, therefore, do not have a strong desire to lift themselves out of poverty, and their attitude toward employment is very casual, which is affecting poverty reduction cooperation and the speed of social progress.

Compared with many regions with scarce natural resources and harsh climatic conditions, Southeast Asian countries in the Mekong River Basin enjoy unique advantages in their development thanks to abundant natural resources and plenty rainfalls. Local populations rely on some simple farming methods to satisfy their basic needs. Hard work and long-term planning seem unnecessary if subsistence is all that is desired to provide life with meaning. For Southeast Asian countries, economic growth at the expense of resource depletion, environmental degradation, and traditional way of life is not desirable; and foreign investment followed by increased carbon footprint is not welcome. Central economic planning and 
state-directed poverty reduction are not familiar notions for Southeast Asian residents as they are for the Chinese. Such internationalist policies as reform and opening up do not sound so attractive to the vast rural populations across the Indochina Peninsula who remain content with their selfseclusion. As long as this gap in development philosophies remains, it seems very difficult for cooperation under the LMC to achieve long-lasting progress in poverty reduction in the Mekong River sub-region.

\section{Conclusion}

Persistent poverty is the biggest obstacle standing in the way of sustained economic development in the Mekong River Basin. Poverty reduction cooperation in recent years has encountered increasing difficulties since great power competition returns as the defining feature of the global geo-strategic landscape. Overlapping sub-regional plans, programs, and initiatives usually lead to institutional duplication and inefficiency. In this regard, compatibility, complementarity and coordination should be the focus of sub-regional institution building on poverty reduction cooperation. To strengthen the relevance and position of the Lancang-Mekong Cooperation mechanism, Beijing must integrate the China-led initiative into the subregional development cooperation landscape. At the same time, such local concerns as development costs, environmental consequences, and resource depletion need to be carefully addressed when China and sub-regional governments are drawing up poverty reduction programs. For China, patience, prudence, and perseverance are the best principles for its cooperation policy in a world increasingly characterized by competition and conflict. 